\title{
DAMPAK PEMANFAATAN MEDIA SOSIAL DALAM INTERAKSI PEMBELAJARAN
}

\author{
Oleh : Riyanto \\ Email : riyantocawas67@gmail.com \\ Sekolah Tinggi Ilmu Komunikasi InterStudi \\ Jl. Wijaya II / 62 Kebayoaran Baru, Jakarta Selatan \\ Telephone : (021) 7262111
}

\begin{abstract}
Abstrak
Internet merupakan produk rekayasa manusia yang memberikan manfaat, kehidupan menjawab hal - hal yang tidak dijangkau secara meteri. Sebagai produk teknologi, internet mampu menjawab setiap perkembangan komunikasi dan informasi dengan interaksi sosial yang berbeda dengan interaksi sosialnya sebelumnya. Seperti dapat diketahui bersama bahwa manusia telah melakukan interaksi di dunia maya secara online, sehingga perkembangan teknologi memiliki alternatif untuk berinteraksi sosial. Internet menghubungkan manusia dari berbagai belahan dunia yang tidak saling mengenal sebelumnya dengan mengkoneksikan komputer jaringan. Interaksi antar manusia sesungguhnya untuk memenuhi kebutuhan hidup jasmani dan rokhani, salah satunya adalah kebutuhan informasi, sebagai tuntutan kehidupan dan penunjang kegiatannya. Penggunaan media sosial semakin meningkat dan menyesuaikan kegunaan sehari - hari seiring perkembangan ilmu pengetahuan dan teknologi yang semakin global. Dengan pendekatan diskriptif penelitian ini berusaha menggambarkan perilaku interaksi sosial di kalangan facebooker, dengan jumlah responden sebanyak 31 orang, dengan mengikuti teknik sampling metode Slovin, diperoleh nilai koefisien determinan $\mathrm{R}_{\text {Square }}=0,998 \mathrm{yang}$ berarti Kinerja kepuasan penggunaan media dipengaruhi oleh 98,8\% dan sisanya 1,2\% dipengaruhi oleh faktor lain yang belum terungkap dalam penelitian ini.
\end{abstract}

\section{Kata kunci: media sosial, kinerja, kepuasan}

\begin{abstract}
The internet is a product of human engineering that provides benefits, responds to things that are not metrically reached. As a technology product, the internet is able to answer every development of communication and information with different social interactions with their previous social interactions. As can be known together that humans have interacted in cyberspace online, so that the development of technology has alternatives for social interaction. The internet connects people from different parts of the world who did not know each other before by connecting computer networks. Interaction between humans is actually to meet the needs of physical life and rokhani, one of which is the need for information, as the demands of life and supporting its activities. The use of social media is increasing and adapting to daily use as developments in science and technology are increasingly global. With a descriptive approach this study seeks to describe the social interaction behavior among Facebookers, with 31 respondents, following the Slovin sampling technique, the $R_{\text {square }}$ determinant coefficient $=0.998$ means that the satisfaction performance of media use is influenced by $98.8 \%$ and the remaining $1,2 \%$ is influenced by other factors that have not been revealed in this study.
\end{abstract}

Keywords: social media, performance, satisfaction 


\section{PENDAHULUAN}

Internet merupakan produk rekayasa manusia yang memberikan manfaat dalam kehidupan manusia, untuk menjawab hal - hal yang tidak dijangkau secara meteri. Sebagai produk teknologi, internet mampu menjawab perkembangan komunikasi dan informasi dengan interaksi sosial berbeda dengan interaksi sosialnya sebelumnya. Manusia melakukan interaksi di dunia maya secara online, merupakan perkembangan teknologi alternatif untuk berinteraksi sosial.

Akses media menjadi kebutuhan primer setiap orang, di berbagai belahan bumi yang berbeda, sehingga teknologi dan informasi yang diproduksi industri, menghadirkan "dunia dalam genggaman".

Perkembangan global membawa perubahan berpikir menjadi global dan tidak mengenal batasan demografi. Perkembangan teknologi informasi dan komunikasi menempatkan internet sebagai basis perkembangan global. Sehingga Wheelan dan Hunger (2008) mengatakan bahwa internet mengubah dunia dengan tujuh cara, antara lain: (1) Jaringan berbasis elektronika untuk konsumen, pemasok dan mitra bisnis (2) Saluran distribusi yang tanpa perantara. (3) Pergeseran kuasa dan keputusan ke konsumen. (4) Perusahaan baru yang menggunakan teknologi dan perusahaan lama yang adaptif menggunakan internet agar lebih efisien dan meningkatkan kecepatan inovasinya (5) Batas perencanaan menjadi lebih pendek, mencerminkan kecepatan internet. (6) Sistem ekstranet telah mengaburkan batas antara pemasok, pembuat dan konsumen.(7) Pengetahuan menjadi sumber untuk keunggulan komparatif.

Aktivitas komunikasi yang dilakukan memiliki tiga tujuan mendasar, untuk memberi dampak (1) kognitif, (2) afektif dan (3) konatif. Dampak kognitif berarti komunikator menyampaikan pesan agar ada perubahan pengetahuan dari lawan komunikasinya. Dampak afektif berarti ada perubahan sikap, dan dampak konatif berarti ada perubahan perilaku. Meskipun komunikasi sudah dimediasi oleh internet, namun tujuan komunikasi tak jauh dari tiga tujuan tersebut.

\section{KAJIAN LITERATUR}

Dalam memaknai perkembangan media, terjadi konvergensi media yang mengubah hubungan antara teknologi, industri, pasar, gaya hidup dan khalayak. Konvergensi secara harfiah adalah dua benda atau lebih yang bertemu dalam satu titik pemusatan pandangan. Konvergensi secara umum, penyatuan berbagai layanan dan teknologi komunikasi serta informasi (ICTS - Information and Communication Technology and Services)..

Pemahaman realitas media sosial merupakan realitas kompleks, dinamis berubah - ubah dan dibangun atas dasar pengguna teknologi. Namun disisi lain, realitas itu membentuk nilai - nilai, memiliki pola, terstruktur dan memunculkan inovasi - inovasi baru sebagai jawaban dari evolusi yang terjadi dalam dunia virtual. Evolusi tidak hanya ditunjukkan dengan pembaharuan, baik perangkat lunak maupun keras tetapi juga manusia sebagai entitas yang menggunakan teknologi maupun berintekasi dengan entitas lain di internet.

Term "mediamorfosis" dipopulerkan oleh Fidller pada 1990-an memberikan pengantar konsep bagaimana teknologi mengubah media menjadi baru. Perubahan 
akibat teknologi itu tidak hanya berimbas pada bisnis media, tetapi juga memberikan determinasi khalayak. Salah satunya konten yang tidak lagi dikuasai institusi media. Fenomena yang muncul dalam jurnalisme, adalah keterlibatan khalayak produksi informasi dan berita, sehingga bisa berkontribusi melaporkan peristiwa secara langsung dan mengakses media sosial.

Khalayak dimedia baru memiliki kekuasaan sepenuhnya dalam membangun relasitas dari interaksi, regulasi, struktur, cara berkomunikasi, bahkan bahasa dalam berkomunikasi. Teknologi sepertinya memberikan pilihan khalayak mengonstruk dirinya di dunia virtual dan berada dalam jaringan, namun keberadaannya sekedar sebagai lukers (Hine:2000) atau pengintip yang tidak meninggalkan jejak. Hine membagi tipe pengguna di media siber dalam konteks group diskusi dalam tiga bentuk yakni: web surver, active newgroup participants dan lukers. Keberadaan pengintai merupakan persoalan tersendiri untuk melihat jejak pengguna komunikasi termediasi komputer. Karena dalam grup diskusi di internet posisi pengintai ini hanya melihat, membaca satu, dua isi yang dipublikasikan, tidak meninggalkan jejak sekalipun. Pengintai dalam konteks ini tidak melakukan interaksi apapun dengan pengguna lainnya.

Secara singkat, budaya di media sosial memiliki bahan dasar yakni konten. Karena komoditas yang diproduksi sekaligus dikonsumsi oleh khalayak di media sosial adalah konten. Konten bisa berarti teks yang ditulis, foto, video, suara dan sebagainya yang disebarkan di media sosial.

Karakteristik media sosial lainnya adalah konten oleh pengguna atau lebih popular disebut user generated content $(U G C)$. Term ini menunjukkan bahwa di media sosial, konten sepenuhnya milik dan kontribusi pengguna atau pemilik akun. UGC merupakan relasi sembiosis dalam budaya media baru yang memberikan kesempatan dan keleluasaan pengguna untuk berpartisipasi.

Dengan teori fungsionalisme struktur, media memberi dukungan pada semua subsistem masyarakat. Dalam konteks ini media dioperasionalkan oleh sejumlah tenaga kerja yang melakukan fungsi ekonomi, artinya media menjadi wahana masyarakat untuk memenuhi kebutuhan individu dan lingkungannya. Selanjutnya media mendukung masyarakat dalam usaha beradaptasi untuk mencapai tujuan individu, tentunya media bukan satu - satunya perangkat.

Siklus hidup industri media yaitu masuknya media pada pasar media, berakhirnya media dari pasar serta kemungkinan bertahannya di pasar media, dapat dilihat dari dua teori, yaitu teori Industrial Organization dan Ecological Organization (Kranenburg:2006)

Menurut teori Industrial Organization (IO), praktik industri media di pandang dari keorganisasian industri meliputi penentuan struktur pasar media, perilaku pasar dan kinerja media. Struktur pasar meliputi kategori jumlah penjual dan pembeli pasar monopoli, oligopoli, atau pasar sempurna, keanekaragaman produk, hambatan memasuki pasar, struktur pembiayaan dan integrasi vertikal. Sedangkan aspek perilaku pasar adalah perilaku dalam penetapan harga, penelitian dan inovasi, perencanaan investasi, taktik legal. Sedangkan elemen dari kinerja pasar media dilihat dari efisiensi produk maupun alokasi perkembangan equity-nya. Dari siklus Struktur Pasar Media, Perilaku Pasar dan Kinerja media, maka sebagai lembaga bisnis kinerjanya diukur dari keuntungan yang diperoleh. 
Teori Ecological Organization (EO) merupakan pendekatan sosiologis dan evolusi industri yang menawarkan persepektif analisis dinamika organisasi yang tergantung pada jumlah populasi organisasi. Ada dua model yang digunakan yaitu model ketergantungan pada jumlah media (Density Depedency Model - DDM) dan batas - batas sumber daya. Model ketergantungan menjelaskan efek jumlah organisasi pada proses masuk keluarnya serta bertahannya industri media di pasar media. Usia industri media dipengaruhi oleh perubahan yang sistematis dari jumlah perusahaan legitimate, kompetisi antar media, tingkatan media yang masuk dan keluar pasar. Model batas - batassumber daya memberikan sumbangan analisis untuk memberikan penjelasan terjadinya pembaruan populasi industri. Dalam melakukan observasi harus menggunakan sumber daya yang spesifik antara lain teknologi dan data konsumen. Model ini melakukan investigasi kompetisi di antara industri yang umum. Kompetisi biasanya ditentukan oleh skala ekonomi. Jika pasar didominasi oleh beberapa industri generalis, maka akan menumbuhkan peluang media spesialis masuk pasar global.

\section{METODE PENELITIAN}

Penelitian ini menggunakan pendekatan kuantitatif dengan tipe penelitian deskriptif. Penelitian diskriptif dimaksudkan untuk menggambarkan interaksi sosial online yang tergabung dalam keanggotaan facebook yang berisikan pembelajaran teori dan praktek yang dilakukan sehari - hari sebagai obyek pembelajaran.

Untuk dapat menggambarkan perilaku interaksi sosial online di kalangan facebooker, maka penelitian melibatkan para facebooker yang terjalin secara online. Dipilih facebook, karena media ini sampai saat ini paling banyak pengguna account facebook di Indonesia pada tahun 2017, merupakan masyarakat maya yang besar dan kemungkinan berinteraksi sesama pengguna facebook sangat besar.

Teknik pengumpulan data dengan mengadakan pencatatan jumlah responden yang melakukan interaksi, baik mengajukan pertanyaan atau memberikan tanda "jempol" atau like dalam tayangan konten manajemen di facebook.

Dari data yang terkumpul dari populasi yang tergabung dalam komunitas facebook dalam account facebook:riyantogaram@yahoo.com dilakukan pencatatan dan pengolahan data, untuk selanjutnya dilakukan analisa dan konsultasi

Populasi adalah kumpulan obyek yang ingin diketahui sifat, jenis dan karakteristik, merupakan koresponden yang tergabung dan aktif dalam riyantogaram@yahoo.com berjumlah kurang lebih 100 orang responden.

Teknik sampling yang digunakan adalah dengan proportionate stratified random sampling.Perhitungan sampel diperoleh dengan menggunakan rumus Slovin :

$$
\mathrm{n}=\frac{\mathrm{N}}{1+\mathrm{Ne}^{2}}
$$

Keterangan : 
$\mathrm{n}=$ Ukuran sampel

$\mathrm{N}=$ Ukuran populasi

$\mathrm{e}=$ Persen kelonggaran ketidaktelitian karena kesalahan pengambilan sampel yang masih dapat ditolerir atau diinginkan, penelitian ini menggunakan $5 \%$.

\subsection{Indikator dan Kisi - Kisi Instrumen Penelitiaan}

Berikut ini adalah indikator - indikator yang akan dituangkan kedaalam butir-butir pernyaataan kuisioner seperti tertuang pada Tabel 3.1, tabel ini adalah untuk variabel Kepuasan Kerja

Tabel 3.1

Indikator Variabel Bebas ( X)

\begin{tabular}{|c|c|c|c|}
\hline Variabel & Dimensi & Indikator & Skala Ukur \\
\hline \multirow{5}{*}{$\begin{array}{l}\quad \text { Kepuasan Kinerja } \\
\text { Menurut } \\
\text { Handoko(2000:193) } \\
\text { "Kepuasan kerja (job } \\
\text { satisfaction) adalah keadaan } \\
\text { emosional yang } \\
\text { menyenangkan atau tidak } \\
\text { menyenangkan bagaimana } \\
\text { para responden memandang } \\
\text { kegiatan mereka". }\end{array}$} & Prestasi yang diraih & 1 dan 2 & Ordinal \\
\hline & $\begin{array}{l}\text { Pengakuan orang } \\
\text { lain }\end{array}$ & 3 dan 4 & Ordinal \\
\hline & $\begin{array}{l}\text { Tanggung jawab } \\
\text { pekerjaan }\end{array}$ & 5 dan 6 & Ordinal \\
\hline & $\begin{array}{l}\text { Kesempatan untuk } \\
\text { maju }\end{array}$ & 7 dan 8 & Ordinal \\
\hline & $\begin{array}{l}\text { Kemungkinan } \\
\text { pengembangan karir }\end{array}$ & 9 dan 10 & Ordinal \\
\hline
\end{tabular}

Sumber : Diolah, 2019

Variabel terikat adalah Media Sosial, dengan kisi-kisi yang dikembangkan secara operasional dijabarkan sebagai Tabel 3.2

Tabel 3.2

Indikator Variabel Terikat ( Y )

\begin{tabular}{|c|c|c|c|}
\hline Variabel & Dimensi & Indikator & $\begin{array}{l}\text { Skala } \\
\text { Ukur }\end{array}$ \\
\hline \multirow{6}{*}{$\begin{array}{l}\text { Media Sosial } \\
\text { Menurut Handoko (1987 } \\
: \text { 135) "kinerja adalah } \\
\text { ukuran terakhir } \\
\text { keberhasilan seorang } \\
\text { responden dalam } \\
\text { melaksanakan kegiatan". }\end{array}$} & Kualitas pekerjaan & 1 dan 2 & Ordinal \\
\hline & Kuantitas pekerjaan & 3 dan 4 & Ordinal \\
\hline & Ketepatan waktu & 5 dan 6 & Ordinal \\
\hline & Efektititas biaya & 7 dan 8 & Ordinal \\
\hline & Pengawasan & 9 & Ordinal \\
\hline & Hubungan rekan sekerja & 10 & Ordinal \\
\hline
\end{tabular}

Sumber : Diolah, 2019 


\subsection{Teknik Pengumpulan Data}

Teknik pengumpulan data mengikuti kaidah - kaidah ilmiah dan dapat diuraikan sebagai berikut: (1) Penelitian kepustakaan merupakan metode pengumpulan data yang diperoleh melalui studi pustaka. Dalam hal ini, mencari dan membaca serta mendapatkan sumber ilmiah di dalam buku-buku, khususnya berkaitan dengan penelitian. (2) Studi lapangan, yaitu cara pengambilan data dengan pengamatan langsung ke obyek penelitian.

Instrumen penelitian diukur dengan skala likert, yaitu skala yang digunakan untuk mengukur sikap, pendapat, dan persepsi seseorang/sekelompok orang tentang isi konten pembelajaran yang ditayangkan pada media sosial facebook pada bulan Agustus - Desember 2018. Variabel yang diukur, dijabarkan ke dalam indikator kinerja media sosial. Sub indikator tersebut dijadikan sebagai titik tolak menyusun item-item instrumen yang berupa pernyataan dalam sebuah kuesioner

\subsection{Pengujian Hipotesis}

Pengujian hipotesis digunakan untuk menguji apakah terdapat kepuasan kinerja terhadap media sosial, maka uji hipotesis menggunakan Distribusi t. Langkah-langkah hipotesis adalah sebagai berikut :

a. Ho $: \rho \leq 0 \quad$ Tidak terdapat pengaruh yang signifikan kepuasan kinerja terhadap media sosial

b. Ha: $\rho>0$ Terdapat pengaruh yang signifikan kepuasan kinerja terhadap media sosial

\section{HASIL DAN DISKUSI}

\subsection{Uji Reliabilitas}

Reliablitias menunjukkan pengertian bahwa instrument dipercaya untuk digunakan sebagai pengumpul data karena dianggap baik. Instrument yang baik akan bersifat tendensius mengarahkan responden memilih jawabannya. Reliabel berarti dapat di percaya, sehingga pengujian mendapatkan nilai yang konsisten.

Uji Variabel menggunakan nilai korelasi Cronbach's alpha of iten deleted seperti yang terlihat dalam tabel 4.5 diperoleh angka $=0,825$ korelasi berada pada kategori yang memiliki hubungan sangat kuat bila di bandingkan dengan $\mathrm{r}_{\text {tabel }}=$ $31(\mathrm{n}-2=31-2)=0,3550$

\section{Tabel 4.5}

Pengujian reliabilitas

Reliability Statistics
\begin{tabular}{|c|r|}
\hline $\begin{array}{c}\text { Cronbach's } \\
\text { Alpha }\end{array}$ & N of Items \\
\hline .825 & 12 \\
\hline
\end{tabular}

Berdasarkan kaidah pengujian reliabelitas, apa bila $r_{\text {hitung }}>r_{\text {tabel }}$ maka variabel dinyatakan reliabel dan apabila $r_{\text {hitung }}<r_{\text {tabel }}$ maka variabel dinyatakan tidak realibel. Dilihat dari hasil perhitungan maka di $r_{\text {hitung }}>r_{\text {tabel }}=0,825>0,3550$ maka variabel tersebut dinyatakanreliabel. 
Dari hasil perhitungan $r_{\text {hitung }}$ dibandingkan dengan $r_{\text {tabel }}$ maka $r_{\text {hitung }}>r_{\text {tabel }}$ maka semua instrument di katakan reliabel karena hasilnya lebih besar dari 0,3550, sedang tingkat keandalan dapat di lihat dalam tabel. 4.6 tingkat koefisien reliabilitas data.

Tabel 4.6

Koefisien Reliabilitas Cronbach's Alpha

\begin{tabular}{|c|c|}
\hline Nilai Cronbach's Alpha & Tingkat keandalan \\
\hline $0.0-0.20$ & Kurang Andal \\
\hline$>0,20-0,40$ & Agak Andal \\
\hline$>0,40-0.60$ & Cukup Andal \\
\hline$>0.60-0.80$ & Andal \\
\hline$>0.80-1.00$ & Sangat andal \\
\hline
\end{tabular}

Sumber : Sugiyono

\subsection{Uji Validitas.}

Merupakan pengukuran ketepatan alat ukur terhadap suatu instrument. Suatu instrument dikatakan valid bila mampu mengukur obyek, sehingga dapat mengungkapkan variabel yang di teliti. Uji validitas dilakukan dengan memperbandingkan pada nilai $\mathrm{r}_{\text {tabel }}$ Product Moment pada $\mathrm{df}=31(\mathrm{n}-2=31-2$ ) $=0,3550$ padatoleransi kesalahan 5\%, sedangkan $\mathrm{r}$ hitung berdasarkan tabel 4.7 di peroleh angka 0,996 sehingga syarat pengujiannya adalah :

1. Jika alat nilai $\mathrm{r}_{\text {-hitung }}>$ nilai $\mathrm{r}_{\text {-tabel}}$, maka butir pernyataan yang diajukan kepada responden dinyatakan valid.

2. Apabila pada nilai $r_{-}{ }_{\text {hitung }}<$ nilai $r_{-}$tabel, maka butir pernyataan atau variabel dinyatakan tidak valid.

Sehingga $r_{\text {hitung }}>r_{\text {tabel }}=0,996>0,3550$ dinyatakan bahwa responden memiliki kevalidan atau kesahian data dalam peneltian

Tabel. 4.7

\section{Tabel Validitas}

\begin{tabular}{|lll|r|}
\hline \multicolumn{2}{c|}{ Reliability Statistics } \\
& & Value & .622 \\
& Part 2 & Nof ltems & $6^{\mathrm{a}}$ \\
& & Value & .613 \\
& Total N of Items & Nof Items & $6^{\mathrm{b}}$ \\
Correlation Between & & 12 \\
& & & .994 \\
Spearman-Brown & Equal Length & & .997 \\
Coefficient & Unequal Length & & .997 \\
Guttman Split-Half Coefficient & .996 \\
\hline
\end{tabular}

a. The items are: Organisasi, Perencanaan, Kelompok, Kegiatan, Pengarahan, Kontrol.

b. The items are: Kinerja, Kebutuhan, Informasi, Lingkungan , Medson, Kepuasan.

Dalam pengujian Validitas Corrected item -Total Correlation yang merupakan korelasi antar nilai yang di peroleh dengan nilai total item (nilai $\mathrm{r}_{\text {hitung }}$ ) 


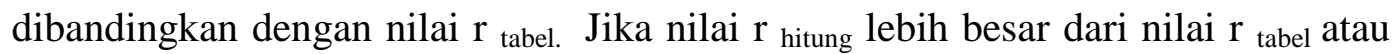
nilai $r_{\text {hitung }}>$ nilai $r_{\text {tabel }}$ maka item tersebut adalah valid dengan menggunakan distribusi tabel $\mathrm{r}$ untuk $\alpha=0,05$ dengan derajat kebebasan $(\mathrm{dk}=\mathrm{n}-2=31-2=$ 29) sehingga di peroleh $r_{\text {tabel }}=0,3550$

Tabel 4.8

Skala Deskripsi

Item-Total Statistics

\begin{tabular}{|l|r|r|r|r|}
\hline & $\begin{array}{c}\text { Scale Mean if } \\
\text { Item Deleted }\end{array}$ & $\begin{array}{c}\text { Scale } \\
\text { Variance if } \\
\text { Item Deleted }\end{array}$ & $\begin{array}{c}\text { Corrected } \\
\text { Item-Total } \\
\text { Correlation }\end{array}$ & $\begin{array}{c}\text { Cronbach's } \\
\text { Alpha if Item } \\
\text { Deleted }\end{array}$ \\
\hline Organisasi & 126.26 & 619.598 & .997 & .747 \\
Perencanaan & 164.61 & 912.312 & .595 & .802 \\
Kelompok & 166.29 & 1058.013 & .273 & .826 \\
Kegiatan & 165.10 & 1073.890 & .206 & .829 \\
Pengarahan & 165.16 & 1083.473 & .124 & .833 \\
Kontrol & 164.45 & 962.989 & .559 & .807 \\
Kinerja & 136.00 & 639.933 & .997 & .746 \\
Kebutuhan & 166.48 & 916.458 & .610 & .801 \\
Informasi & 168.23 & 1067.514 & .242 & .827 \\
Lingkungan & 167.10 & 1073.890 & .206 & .829 \\
Medson & 167.10 & 1092.824 & .089 & .835 \\
Kepuasan & 166.45 & 962.989 & .559 & .807 \\
\hline
\end{tabular}

Sumber: diolah 2019

Dengan membandingkan hasil perhitungan tabel data Total Item Statistics maka tidak semua variabel memiliki tingkat validitas yang memiliki nilai $\mathbf{r}_{\text {hitung }}<0,3550$

\subsection{Uji Normalitas Data}

Normalitas data dapat diketahui dengan menggunakan program SPSS dengan analisa One - Sample Kolmogrov - Smirnov Tes sehingga diketahui normalitas data, sehingga tabel 4.9 di peroleh informasi bahwa:

KinerjaMedia Sosial $(\mathrm{X})=0,632$ yang artinya $>0,05$ maka Populasi data tersebut memiliki distribusi normal karena uji Kolmogorov-Smirnov (K-S). Atau $\mathrm{K}-\mathrm{S}_{\text {hitung }}>\mathrm{K}-\mathrm{S}_{\text {tabel }}$ (nilai probabilitas data atau $0,05(\mathrm{dk}=\mathrm{n}-2=31-2=29)$ sehingga di peroleh $\mathrm{r}_{\text {tabel }}=0,3350$ ), maka $\mathrm{H}_{0}$ dinyatakan di terima, dan bila K-S hitung $<\mathrm{K}-\mathrm{S}$ tabel maka $\mathrm{H}_{1}$ di tolak. Dengan membandingkan di peroleh informasi besarnya nilai $\mathrm{K}-\mathrm{S}_{\text {hitung, }}$, terhadap nilai $\mathrm{K}-\mathrm{S}_{\text {tabel }}=0,632>0,3550$, sehingga $\mathrm{H}_{0} \mathrm{di}$ terima dan dinyatakan data memiliki normalitas.

Tabel 4.9

Uji Normalitas Data 
One-Sample Kolmogorov-Smirnov Test

\begin{tabular}{|ll|r|r|}
\hline & & \multicolumn{1}{|c|}{ Kineria } & Media Sosial \\
\hline $\mathrm{N}$ & & 31 & 31 \\
Normal Parameters ${ }^{\mathrm{a}, \mathrm{b}}$ & Mean & 48.58 & 38.84 \\
& Std. Deviation & 8.578 & 8.174 \\
Most Extreme & Absolute & .113 & .132 \\
Differences & Positive & .113 & .132 \\
& Negative & -.094 & -.076 \\
Kolmogorov-Smirnov Z & & .632 & .737 \\
Asymp. Sig. (2-tailed) & & .820 & .650 \\
\hline
\end{tabular}

a. Test distribution is Normal.

b. Calculated from data.

\subsection{Analisis Regresi Linier}

Analisis untuk mengetahui seberapa besar pengaruh variabel bebasdengan variabel terikatpada responden dalam pertemanan dalam facebook.com khususnya pada https://www.facebook.com/riyantogaram

Persamaan regresinya adalah sebagai berikut:

Dimana :

$$
\hat{\mathbf{Y}}=\mathbf{a}+\mathbf{b X}
$$

$\mathrm{Y} \quad=$ Media Sosial

a $\quad=$ Y pintasan, (nilai $\hat{Y}$ bila $\mathrm{X}=0$ ) atau konstanta

$\mathrm{b} \quad=$ Mengukur besarnya pengaruh $\mathrm{X}$ terhadap $\mathrm{Y}$ jika $\mathrm{X}$ naik satu unit

$\mathrm{X} \quad=$ Kinerja responden

Data dalam regresi linear sederhana pada penelitian ini diambil dari tabel 4.10.

Tabel 4.10

Deskripsi Statistik

One-Sample Statistics

\begin{tabular}{|l|r|r|r|c|}
\hline & & & & Std. Error \\
& $\mathrm{N}$ & Mean & Std. Deviation & \begin{tabular}{c} 
Mean \\
\hline Kinerja
\end{tabular} \\
Media Sosial & 31 & 48.58 & 8.578 & 1.541 \\
\hline
\end{tabular}

Sumber : diolah 2019

Tabel 4.10 menyajikan variabel Kinerja Media (X) terhadap variabel Media Sosial (Y), hasil descriptive variabel Kinerja(X) dijelaskan dengan jumlah kasus $(\mathrm{N})=31$ rata - rata, sebesar 48.58 dan simpangan baku $=8,578$ dan hasil deskripsi statistic Media Sosial (Y) dalam tabel dijelaskan bahwa terdapat sejumlah kasus $(\mathrm{N})=31$, rata - rata sebesar 38.84 dan simpangan baku $=8.174$

Tabel 4.11

Uji Anova 


\begin{tabular}{|c|c|c|c|c|c|c|}
\hline \multicolumn{7}{|c|}{ ANOVA $^{b}$} \\
\hline Model & & $\begin{array}{l}\text { Sum of } \\
\text { Squares }\end{array}$ & df & Mean Square & $\mathrm{F}$ & Sig. \\
\hline 1 & Regression & 1980.422 & 1 & 1980.422 & 2415.957 & $.000^{2}$ \\
\hline & Residual & 23.772 & 29 & .820 & & \\
\hline & Total & 2004.194 & 30 & & & \\
\hline
\end{tabular}

a. Predictors: (Constant), Kinerja

b. Dependent Variable: Media Sosia

Sumber : diolah 2019

Uji Anova ditampilkan hasil nilai $\mathrm{F}=2415,957$ dengan tingkat probabilitas sig.0,0001. Oleh karena probabilitas $(0,0001)$ jauh lebih kecil dari 0,05 maka model regresi tersebut dapat digunakan untuk memprediksi kepuasan kinerja responden .

Tabel 4.10

Regresi Linier

\begin{tabular}{|c|c|c|c|c|c|c|}
\hline \multicolumn{7}{|c|}{ Coefficients } \\
\hline \multirow[b]{2}{*}{ Model } & & \multicolumn{2}{|c|}{$\begin{array}{c}\text { Unstandardized } \\
\text { Coefficients }\end{array}$} & \multirow{2}{*}{$\begin{array}{c}\begin{array}{c}\text { Standardized } \\
\text { Coefficients }\end{array} \\
\text { Beta }\end{array}$} & \multirow[b]{2}{*}{$\mathrm{t}$} & \multirow[b]{2}{*}{ Sig. } \\
\hline & & $B$ & Std. Error & & & \\
\hline & (Constant) & -7.175 & .950 & & -7.551 & .000 \\
\hline & Kinerja & .947 & .019 & .994 & 49.152 & .000 \\
\hline
\end{tabular}

a. Dependent Variable: Media Sosial

Sumber : diolah 2019

Hasil uji koefisien terdapat nilai konstan $=(7,175)$ dan nilai $\mathrm{B}=0,947$ serta nilai $\mathrm{t}$ hitung dengan tingkat signifikan $=0,0001$, sehingga persamaan hitungan regresi sederhana; $\mathrm{Y}=\mathrm{a}+\mathrm{bX}=-7,175+0,947 \mathrm{X}$. Koefisien regresi sebesar 0,947 menyatakan setiap penambahan kepuasankinerja satu point diprediksi akan meningkatkan fungsi media sosial sebesar 0,947 , demikian juga apabila terjadi penurunan

Persamaan $(\mathrm{Y}=-7,175+0,947 \mathrm{X})$ di uji apakah memang valid untuk memprediksi variabel dependen, maka dilakuka pengujian signifikasi, dari tabel koefisien diperoleh $\mathrm{t}_{\text {hitung }}=-7,551$ dengan tingkat signifikan 0,05 maka df atau $\mathrm{dk}$ (derajat kebebasan) $=\mathrm{N}-2$ atau $31-2=29$ sehingga di peroleh angka $\mathrm{t}_{\text {tabel }}$ $=0,683$, dan ternyata nilai $\mathrm{t}_{\text {hitung }}>\mathrm{t}_{\text {tabelatau }}-7,551>0,683$ artinya signifikan, sehingga kepuasan kinerja berpengaruh kepada media sosial.

\subsection{Analisis Koefisien Korelasi ( $r$ ) dan Determinasi $\left(r^{2}\right)$}

Korelasiantara variabel bebas (X) dalam hal ini Kinerjadan variebel terikat (Y) atau Media Sosial dapat diketahui dari koefisien korelasi yang menunjukkan kekuatan hubungan antara variabel bebas dengan variabel terikat. Porsi pengaruh dilihat pada kolom R Square, yang berarti eratnya pengaruh antar yang diteliti. Hasil perhitungan tersebut ditunjukan Tabel 4.11.

Tabel 4.11

\section{Koefisiensi Korelasi dan Determinasi}




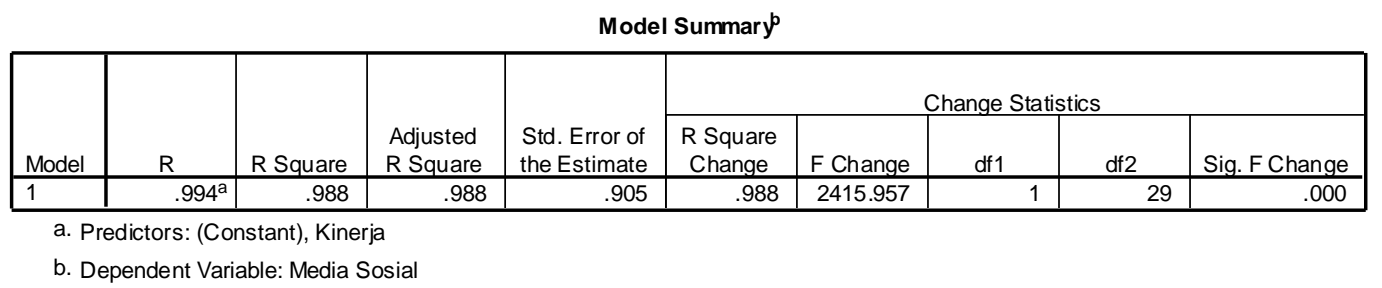

Sumber : diolah 2019

Dari Tabel 4.11 Koefisien Korelasi dan Determinasi (model summary) diperoleh nilai $\mathrm{R}=0$, 994 dan koefisien determinasi $(\mathrm{R}$ square) sebesar $=0,988$ yang merupakan pengkuadratan dari nilai $0,994^{2}=0,988$. Hal ini menunjukkan pengertian bahwa Kinerja (X) dipengaruhi 98,8\% oleh Media Sosial (Y) sedangkan sisanya sebesar $(100 \%-98,8 \%=1,2 \%$ di pengaruhi oleh faktor lain. Kisaran angka $\mathrm{R}_{\text {square }}$ pada angka 0 sampai 1 , dan semakin kecil angka $\mathrm{R}$ square menunjukkan semakin lemah hubungan kedua variabel tersebut.

\subsection{Uji Hipotesis}

Hipotesis yang di uji umumnya disebut nol hypothesis dengan simbol $\mathrm{H}_{0}$, untuk menguji kebenaran pengaruh antara variabel $\mathrm{X}$ dan variabel $\mathrm{Y}$ dengan menggunakan uji dua arah dengan asumsi taraf nyata adalah 5\% serta derajat kebenaran (df) adalah n-2. Pengujian hipotesis atas koefisien regresi variabel bebas, yaitu apakah korelasi variabel bebas (kepuasan kinerja) dengan variabel terikat (media sosial), pengujian tingkat signifikansi, membandingkan nilai t-hitung dengan $t_{-t a b e l}$. Dan dari tabel 4.10 dapat di peroleh angka $t_{\text {hitung }}=7,551$ dan $t_{\text {tabel }}$ sebesar df atau dk $-2=31-2=29$ dari t tabel di peroleh angka sebesar $=0,683$ sehingga kaidah $\mathrm{t}_{\text {hitung }}>\mathrm{t}$ tabel $=7,551>0,683$, maka dipastikan variabel tersebut signifikan. Hal itu dapat dilihat pada Tabel 4.12

Tabel 4.12

Nilai Koefisien $\mathbf{T}$ - Hitung

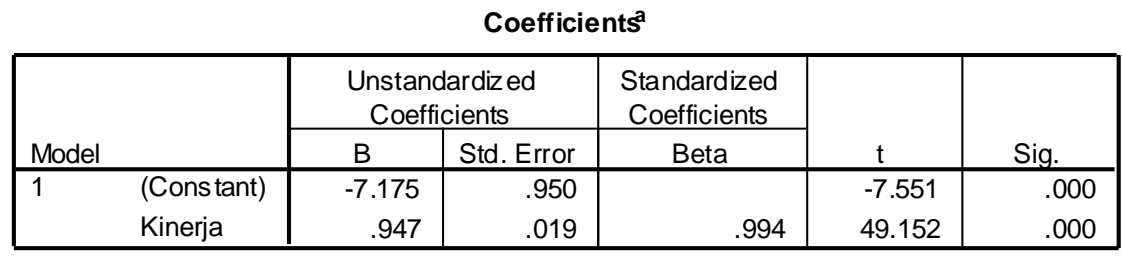

a. Dependent Variable: Media Sosial

Sumber : diolah 2019

\section{PEMBAHASAN}

Berdasakan Uji Variabel menggunakan Guttman Split - Half Coefisien seperti yang terlihat dalam tabel 4.6 diperoleh angka $=0,996$ korelasi berada pada kategori yang memiliki hubungan sangat kuat bila di bandingkan dengan $\mathrm{r}_{\text {tabel }}=$ $31(\mathrm{n}-2=31-2)=0,3550$. Berdasarkan kaidah pengujian reliabelitas, apa bila $\mathrm{t}$ hitung $>\mathrm{t}$ tabel maka variabel dinyatakan reliabel dan apabila $\mathrm{t}$ hitung $<\mathrm{t}$ tabel maka variabel dinyatakan tidak realibel. Dilihat dari hasil perhitungan maka di $\mathrm{t}_{\text {hitung }}>\mathrm{t}$ tabel $=0,996>0,3550$ maka variabel tersebut dinyatakanreliabel. 
Dalam Tabel 4.7dapat terlihat bahwa variabel $\mathrm{X}$ dan variabel $\mathrm{Y}$ yang telah diteliti, masing-masing variabel memiliki 31 (tiga puluh satu) instrumen dengan $\mathrm{r}$ hitungdi peroleh angka $=0,996$ lebih besar jika dibandingkan dengan $r_{\text {-tabel. }}=\mathrm{dk}-2$ $=31-2=1$ berdasarkan tabel di peroleh angka $=0,3550$ sehingga berdasarkan kreteria validitas apabila terpenuhi kaidah $r_{\text {hitung }}>r_{\text {tabel }}=0,7996>0,3550$ akan memenuhi tingkat validitas responden.

Tingkat normalitas program SPSS dengan analisa One - Sample Kolmogrov - Smirnov Tes, diketahui normalitas data penelitian ini, sehingga tabel 4.5 dengan metode Kolmogorov - Smirnov Tes di peroleh informasi bahwa:

Kepuasan Kerja $(\mathrm{X})=1,264$ yang artinya $>0,05$ maka Populasi data tersebut memiliki distribusi normal karena uji Kolmogorov-Smirnov (K-S). Atau K- S hitung $>\mathrm{K}-\mathrm{S}$ tabel (nilai probabilitas data atau 0,05), maka $\mathrm{H}_{0}$ dinyatakan di terima,

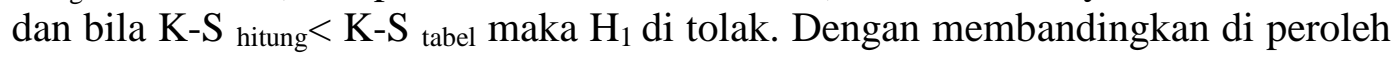

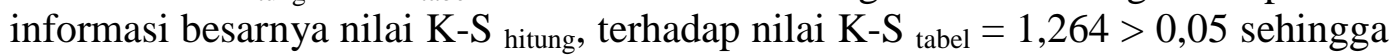
$\mathrm{H}_{0}$ di terima dan dinyatakan data memiliki normalitas. Sehingga berdasarkan tabel 4.5 kedua variabel lebih besar dari 0,186 maka dinyatakan memiliki distribusi normal.

Dari hasil uji koefisien terdapat nilai konstan $=17,687$ dan nilai $\mathrm{B}=0,526$ serta nilai $\mathrm{t}$ hitung dengan tingkat signifikan $=0,0001$, sehingga diperoleh persamaan hitungan regresi sederhana $\mathrm{Y}=\mathrm{a}+\mathrm{bX}=17,687+0,526 \mathrm{X}$. Koefisien regresi sebesar 0,526 menyatakan setiap penambahan kepuasan kinerja satu point diprediksi akan meningkatkan media sosial sebesar 0,526, demikian juga apabila terjadi penurunan

Persamaan $(\mathrm{Y}=17,687+0,526 \mathrm{X})$ di uji apakah memang valid untuk memprediksi variabel dependen, maka dilakukan pengujian signifikasi dan diperoleh koefisien diperoleh $\mathrm{t}_{\text {hitung }}=5,128$ dengan tingkat signifikan 0,05 maka df atau dk (derajat kebebasan) $=\mathrm{N}-2$ atau $53-2=51$ sehingga di peroleh angka $\mathrm{t}_{\text {tabel }}=0,679$, dan ternyata nilai $\mathrm{t}_{\text {hitung }}>\mathrm{t}_{\text {tabel }}$ atau 5,128 $>0,679$ artinya signifikan, sehingga kepuasan kinerja berpengaruh kepada media sosial.

Dari Tabel 4.7 Koefisien Korelasi dan Determinasi diperoleh nilai $\mathrm{R}=0$, 583 dan koefisien determinasi ( $\mathrm{R}$ square) sebesar $=0,340$ yang merupakan pengkuadratan dari nilai $0,583^{2}=0,340$, menunjukkan pengertian media sosial $(\mathrm{Y})$ dipengaruhi secara simultan $34 \%$ oleh Kepuasan kinerja (X) sedangkan sisanya sebesar $(100 \%-34 \%=66 \%$ di pengaruhi oleh faktor lain yang tidak di teliti. Kisaran angka $\mathrm{R}_{\text {square }}$ pada angka 0 sampai 1 , dan semakin kecil angka $\mathrm{R}$ square menunjukkan semakin lemah hubungan kedua variabel tersebut.

\section{DAFTAR PUSTAKA}

Abidin, Y. Z. (2015). Manajemen Komunikasi. Bandung: Pustaka Setia.

Dyah Alyusi, S. (2018). Media Sosial: Interaksi, Identitas dan Modal Sosial. InterKomunikas, Stikom InterStudi.

Idris, I. K. (2012). Internet dan Media Interaktif, Succestory Integrated marketing Communication. Jakarta: Gramedia Pustaka Utama.

Kriyantono, R. (2014). Teknik Praktis Riset Komunikasi. Jakarta: Kencana Prenada Media Group. 
Nasional, P. D. (2017). Pengguna Account Facebook di Indonesia. Jakarta: Data Pusat Statistik Nasional.

Nasrullah, R. (2016). Media Sosial, Perspektif Komunikasi, Budaya dan Sosioteknologi. Bandung : Simbiosa Rekatam Media.

Riyanto. (2017). Efektivitas Media Internet terhadap Kepuasan Media Khalayak. Jakarta: Interkomunika, Stikom InterStudi.

Romli, K. (2016). Komunikasi Massa. Jakarta: Gramedia Widiasarana Indonesia.

Rosadi, U. (2015). Kajian Media : Isu Ideologis . Jakarta: PT. Rajagrafindo Persada.

Rusyana, R. d. (2013). Aplikasi Statistik Penelitian. Bandung: Alfabeta, Bandung.

Shiefti, D. A. (2016). Media Sosial: Interaksi Indentitas dan Modal Sosial. Jakarta: Prenada Media Group.

Soefijanto, T. A. (2012). Integrated Marketing Communication. Jakarta: PT. Gramedia Pustaka Utama.

Soerjono, S. (2013). Sosiologi Suatu Pengantar. Jakarta: PT. Raja Grafindo Persada.

Turnet, R. W. (2010). Introducting Communication Theory : Analysis And Application. New Yorks: Mc Graw Hill.

Winarso, H. P. (2005). Sosiologi Komunikasi Massa. Jakarta: Prestasi Pustaka Publisher. 